\title{
Implementation of One Health Program by Improving Waste Management on Universitas Widya Husada Semarang (UWHS) Campus
}

\author{
Hargianti Dini Iswandari ${ }^{1}$, Ari Dina Permana Citra $^{2 *}$, and Purwanto Purwanto ${ }^{3,4}$ \\ ${ }^{1}$ Study Program of Medical Informatics, Universitas Widya Husada Semarang, Semarang, Indonesia \\ ${ }^{2}$ Study Program of Optometry, Universitas Widya Husada Semarang, Semarang, Indonesia \\ ${ }^{3}$ Green Technology Research Center, School of Postgraduate Studies, Universitas \\ Diponegoro, Semarang, Indonesia \\ ${ }^{4}$ Department of Chemical Engineering, Faculty of Engineering, Universitas Diponegoro, \\ Semarang, Indonesia
}

\begin{abstract}
The concept of One Health was adopted by WHO for the global flu program as well as the pandemic due to coronavirus (Covid 19) which is also related to animals, and the relationship to the humans. Universitas Widya Husada Semarang (UWHS) is one of the educational institutions in the field of health sciences. Current practical activities generate medical and non-medical waste, should be managed appropriately to prevent and reduce the environment pollution. This research objective is to describe the waste management in relation with the implementation of One Health program. Data collection is conducted by interviewing laboratory personnel, observation and measurement of the weight, volume and composition of medical waste, from 8 laboratory rooms. Weight measurement for 12 months, 7 months before pandemic and 5 months after pandemic. The average weight of medical waste in UWHS before the pandemic is $3-5 \mathrm{~kg}$ every month and about $1 \mathrm{~kg}$ during the pandemic. The waste consists of syringes, needles, plabot infuses, infuse hoses, injection cases, injection cotton and rubber gloves. The incineration of hazardous waste carried out by third party. In order to realize the concept of one health, waste management must be strictly guarded to ensure waste management properly.
\end{abstract}

\section{Introduction}

The use of chemicals in health higher education related to human health and the environment in the institution. Various toxic chemicals and infectious substances are used in the laboratory for practical learning for students and research for faculty members. The effects of chemicals on human health could be present in the short and long term. Good management practices the use of chemicals is intended so that the personnel who use the materials are guaranteed their safety and health.

The use of chemicals and substances in health educational institutions also creates hazardous waste. Higher education and medical institutions generate medical waste as

\footnotetext{
* Corresponding author : dinacitra@gmail.com
} 
hazardous waste, cause human health problems and pollute the environment if not managed properly.

Hassanvand et al. examined hazardous waste management at educational institutions and research centres at the Tehran University of Medical Sciences Central Campus, Iran [1]. The results showed that hazardous waste consisted of infectious, toxic, ignitable, carcinogenic, corrosive, and reactive waste, not appropriately managed.

Research conducted by Chima et al. on the waste management practices of health institutions in Yenegoa, Nigeria [2], revealed that standard operating practices are not followed in biomedical waste management. Medical waste is disposed of in public and open trash bins, so waste management experts' education, supervision, and training are needed to handle it.

Hirani et al. [3], Shareefdeen [4] wrote about biomedical waste management starting from waste generation, handling and processing of waste using infected methods, incineration and new technologies. Segregation of ordinary waste with biomedical waste is needed as a first step in handling waste. The next step is to sort biomedical waste based on its characteristics in order to facilitate waste management.

Pramestyawati examined hazardous and toxic waste in clinical laboratories dominated by infectious clinical waste [5]. Management of hazardous and toxic waste is technically based on the generation and type of hazardous waste within the scope of a clinical laboratory as a source of waste. The hazardous clinical temporary storage waste uses a refrigerator to store clinical waste for a maximum of 90 days. Clinical laboratories need Temporary Storage Waste to store hazardous and toxic before being brought by a third party.

Hazardous waste management in an educational institution as an effort to realize the One Health program is carried out at Universitas Widya Husada Semarang (UWHS). The One Health Program was reviewed by Aliyi, which emphasizes the multidisciplinary approach of the professionals with the education system as one of its pillars [6].

Docherty and Foley conducted a One Health Program survey at medical school educational institutions in the US, emphasizing introducing concepts such as One health into the medical school curriculum [7].

UWHS has 11 study programs consisting of 8 health study programs and three non-health study programs. Using materials for practicum and research generates medical and nonmedical waste that needs to be appropriately managed to prevent adverse impacts on university personnel and the environment.

According to Purwanto et al., Purwanto and Citra, the waste management hierarchy include identifying hazardous and non-hazardous waste generation, opportunities for waste recycling on-site or with third parties, feasibility evaluation, and implementation $[8,9]$. This management model is implemented in the packaging industry, which generates hazardous waste during the manufacturing of cosmetic packaging.

This article discusses waste management at Universitas Widya Husada Semarang, Indonesia, starting from identifying medical and non-medical waste generation before and during the Covid 19 pandemic, waste handling, and opportunities for hazardous waste management.

\section{Methods}

The research was conducted on Universitas Widya Husada Semarang (UWHS), Semarang City, Indonesia. UWHS is an educational institution that has eight health study programs. The research steps include identifying waste, measurement of weight and volume of waste, management of medical waste including sorting, temporary storage, transportation, and opportunities for utilization and treatment of medical waste. Data collection is conducted by 
interviewing laboratory personnel, observing and measurement of the weight, volume, and composition of medical waste from 8 laboratory rooms. A weight measurement of waste was carried out for 12 months, seven months before the pandemic, and five months after. Identification of waste generation was carried out before and during the Covid 19 pandemic in 11 study programs. Waste management using process flow diagrams is used to find out opportunities for reducing waste generation and recycling. Assessment of compliance and non-compliance with hazardous waste and medical waste regulations accomplished regarding hazardous waste and medical waste. The conformity and non-conformity of waste management are evaluated using standards. The continuous improvement of medical waste on UWHS is made based on the cycle of waste management.

\section{Result and Discussion}

\subsection{Identification of Waste Generation}

UWHS has two faculties consisting of 11 study programs, namely eight health study programs and 11 non-health study programs. The health study program uses hazardous chemicals, infectious substances, and medical equipment for practicum and laboratory research.

Management of hazardous and toxic materials refers to Government Regulation No. 74 of 2021 concerning Management of Hazardous and Toxic Materials [10], Regulation of the Minister of Health of the Republic of Indonesia No. 75 of 2014 concerning Public Health Centers [11], and Regulation of Minister of Health No. 7 of 2019 concerning Hospital Environmental Health [12]. Hazardous and toxic waste generation mainly comes from using materials and equipment in practicum and research activities. Hazardous and Toxic Waste Management refers to Government Regulation No. 22 of 2021 concerning the Implementation of Environmental Protection and Management [13]. Laboratory waste is categorized as hazardous and toxic waste with flammable, toxic, corrosive, and infectious waste characteristics.

\subsection{Weight of medical waste generation}

Waste generation at UWHS is measured by weighing both before and during the pandemic. The measurement result is presented in Table 1.

The average weight of medical waste on UWHS before the pandemic was $0.0062 \mathrm{~kg} /$ day (3-5 $\mathrm{kg}$ every month) with a standard deviation of $0.0012 \mathrm{~kg} /$ day. The average weight of medical waste during the pandemic was $0.0027 \mathrm{~kg} /$ day (about $1 \mathrm{~kg}$ per month) with a standard deviation of $0.0004 \mathrm{~kg} / \mathrm{day}$. The decrease in medical waste generation during the Covid 19 pandemic was due to the reduced frequency of practicum and research on campus.

Table 1. Average weight of medical waste on UWHS

\begin{tabular}{|c|c|c|c|c|c|}
\hline Period & $\begin{array}{c}\text { Minimum } \\
(\mathrm{kg})\end{array}$ & $\begin{array}{c}\text { Maximum } \\
(\mathrm{kg})\end{array}$ & $\begin{array}{c}\text { Average } \\
(\mathrm{kg})\end{array}$ & $\begin{array}{c}\text { Deviation } \\
(\mathrm{kg})\end{array}$ & $\mathrm{N}$ \\
\hline
\end{tabular}




\begin{tabular}{|l|l|l|l|l|l|}
\hline 1. before pandemic & 0.0051 & 0.0084 & 0.0062 & 0.0012 & 8 \\
\hline 2. during pandemic & 0.0019 & 0.0036 & 0.0027 & 0.0004 & 19 \\
\hline
\end{tabular}

\subsection{Volume of medical waste generation}

Waste generation at UWHS is also measured by volume, both before and during the pandemic. The measurement result is presented in Table 2.

Table 2. Average volume of medical waste on UWHS.

\begin{tabular}{|c|c|c|c|c|c|}
\hline Period & $\begin{array}{c}\text { Minimum } \\
\text { (liter) }\end{array}$ & $\begin{array}{c}\text { Maximum } \\
\text { (liter) }\end{array}$ & $\begin{array}{c}\text { Average } \\
\text { (liter) }\end{array}$ & $\begin{array}{c}\text { Deviation } \\
\text { (liter) }\end{array}$ & $\mathrm{N}$ \\
\hline 1. during pandemic & 0.0564 & 0.0965 & 0.0700 & 0.0153 & 8 \\
\hline 2. during pandemic & 0.0095 & 0.0233 & 0.0148 & 0.0042 & 19 \\
\hline
\end{tabular}

The average volume of medical waste at UWHS decreased during the pandemic period before the pandemic by $78.85 \%$, as shown in Table 2 . This decrease in volume affected the container for waste management at the next step.

\subsection{Medical waste composition}

The waste consists of syringes, needles, infusion plabot, infusion hoses, injection cases, injection cotton, and rubber gloves. The composition of medical waste during the pandemic has changed with the increasing use of sharp objects.

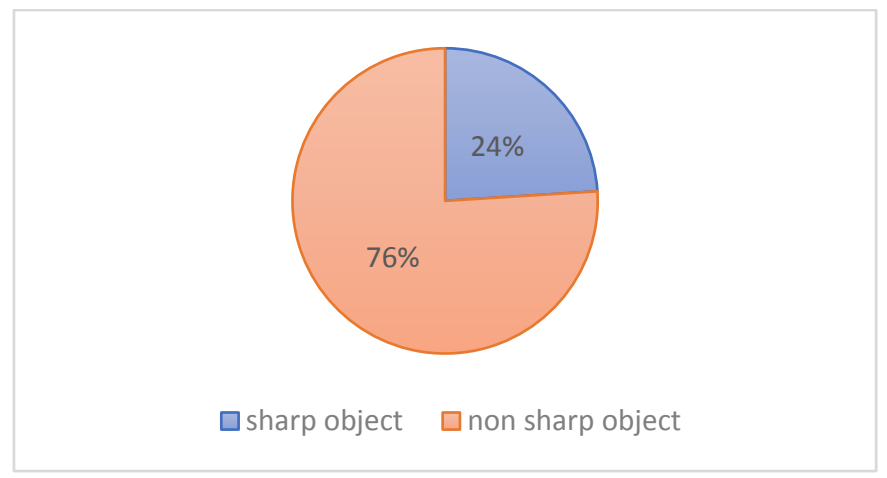

Fig. 1. Waste composition on UWHS before pandemic.

In the pre-pandemic period, medical waste was dominated by non-sharp objects (including infusion plates) as much as $76 \%$, as shown in Figure 1. 


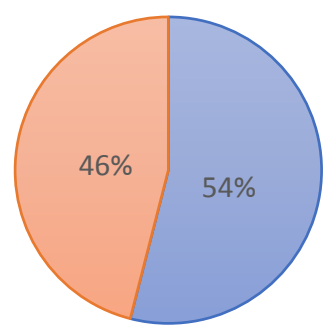

$\square$ sharp object $\square$ non sharp object

Fig. 2. Waste composition on UWHS during pandemic.

The pandemic period changed the composition of medical waste, which was initially dominated by sharp objects such as syringes, needles, catheters, decreased from 76 to 54\%, with the least amount of gauze and cotton waste generation, and no infusion plot.

\subsection{Management of medical waste}

Medical waste management from the laboratory is realized based on standard operating procedures and is guided by the regulations of hazardous and toxic wastes. The management steps carried out on UWHS are shown in Figure 3, starting from a waste generation at the source to the management of waste by a third party.

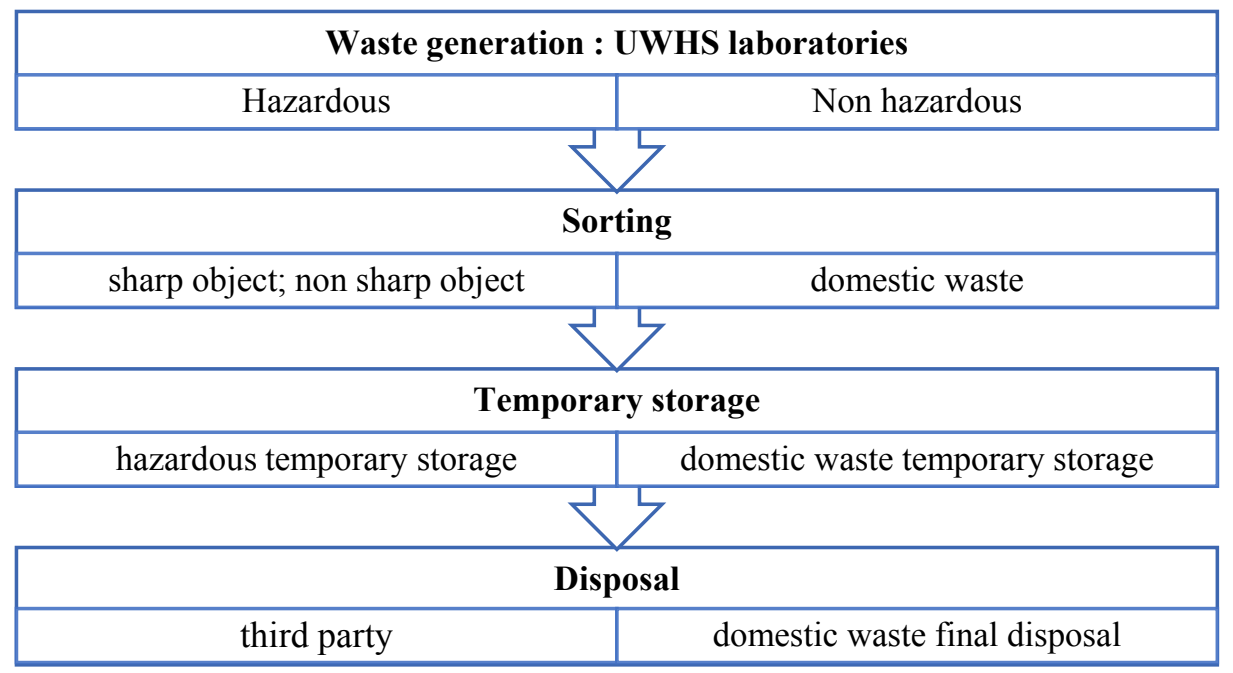

Fig. 3. Waste management on UWHS.

Waste generation from the UWHS laboratories is sorted according to the categories of medical and non-medical waste. Non-medical waste as domestic waste is managed separately, emphasising good sorting by preventing the mixture with medical waste. On the other hand, waste food and drink are still often found in infectious medical waste, resulting 
in an increase in the volume and weight of the medical waste. Disobedience to Regulation of Ministry of Health No. 7 of 2019 and Government Regulation No 22 of 2022 as findings of medical waste management on UWHS need to be improved regarding sorting medical and non-medical waste, especially at the source of waste generation.

Non-medical solid waste is domestic waste, managed from sorting, transportation, and storage at Temporary Disposal Sites (TPS). The sorting of recyclable materials carried out at the TPS includes paper, plastic, rubber, and metal. This waste recycling is carried out by a third party as a functional product, while the residue is transported to the Semarang City Final Disposal Site (TPA).

Medical waste storage is temporarily stored on UWHS in a waste source room or integrated laboratory by medical waste storage requirements. UWHS laboratories use containers made of solid materials, light enough, rust-resistant, waterproof, easy-to-clean containers, tightly closed, containers equipped with medical waste writing and placed out of public reach and containers cleaned periodically.

The displacement of medical waste on UWHS is carried out every day by the cleaning service officers of each laboratory room. The collected waste is taken to the Temporary Storage Place (TPS) for hazardous waste. Officers brought trash cans with yellow plastic containing medical waste to a temporary hazardous waste collection place and then replaced the plastic with new ones. In this transfer process, the cleaning service officers use disposable gloves and masks as Personal Protective Equipment (PPE). According to the Regulation of Minister of Health No. 7 of 2019, medical waste from the waste source to the hazardous TPS should use a special transport trolley to avoid nosocomially.

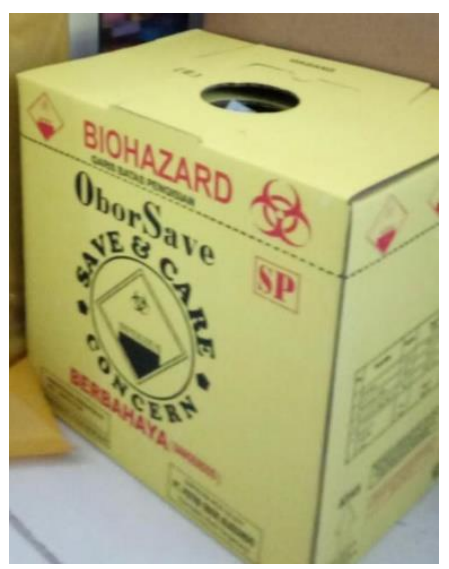

Fig. 4. Temporary disposal for medical waste.

Medical waste on UWHS is stored on-site for up to 3 months duration at room temperature. The condition of temporary storage for medical waste on UWHS is based on the Regulation of Ministry of Health No. 7 of 2019. Meanwhile, infectious waste management is not meet the regulation, as stated that infectious medical waste should be destroyed every week.

The definitive treatment of medical waste at UWHS uses the services of a third party which is obtained a permit from the Ministry of Environment and Forestry. A form notifies 
the service of the third party to UWHS of a cooperation agreement. UWHS ensures that the final treatment of medical waste is carried out by technical requirements to comply with hazardous including toxic and infectious waste treatment regulations.

\section{Conclusion}

Laboratory waste management on Universitas Widya Husada Semarang (UWHS) starts from the source of waste generation by sorting medical and non-medical waste. Non-medical as domestic waste is recycled, and the residue is then disposed of to the Final Disposal Site. Infectious medical waste is managed based on standard operating procedures referring to hazardous and infectious waste management regulations. Reasonable management efforts accomplished by UWHS to prevent and reduce negative impacts on health and the environment. The continuous improvements of waste management on UWHS are also part of realizing the One Health Program to prevent the spread of the Covid 19 pandemic on campus.

\section{References}

1. M.S. Hassanvand, K. Naddafi, R. Nabizadeh, F. Momeniha, A. Mesdaghinia, K. Yaghmaeian, Hazardous waste management in educational and research centers: a case study, Toxicological \& Environmental Chemistry, 93 (8), 1636-1642 (2011), https://doi.org/10.1080/02772248.2011.602683

2. G.N. Chima, I.C. Ezekwe, N.O. Digha, An assessment of medical waste management in health institutions in Yenagoa, South-South, Nigeria, World Review of Science,

Technology and Sust. Development, 8 (2/3/4), 224-233 (2011), https://doi.org/10.1504/WRSTSD.2011.044219

3. D.P. Hirani, K.R. Villaitramani, S.J. Kumbhar, Biomedical waste : An introduction to its management, IJIRAE, 1 (8), 82-87 (2014), https://ijirae.com/volumes/vol1/issue8/SPCE10080.12.pdf

4. Z.M. Shareefdeen, Medical waste management and control, Journal of Environmental Protection, 3, 1625-1628 (2012), doi:10.4236/jep.2012.312179

5. T.N. Pramestyawati, Pengelolaan limbah berbahaya dan beracun (B3) laboratorium klinik di sumber limbah (Hazardous waste management on clinical laboratory at waste sources), Prosiding Seminar Teknologi Perencanaan, Perancangan, Lingkungan, dan Infrastruktur. FTSP ITATS, 2715-4599 (2019), https://ejurnal.itats.ac.id/stepplan/article/view/817

6. S. Aliyi, T. Birhanu, A. Gizachew, T. Kebeta, One health program: its future implications, challenges and opportunities: review, Nat Sci., 13 (8), 59-65 (2015), http://www.sciencepub.net/nature/ns130815/009_28977ns130815 59 65.pdf

7. L. Docherty, P.L. Foley, Survey of one health programs in U.S. medical schools and development of a novel one health elective for medical students, 12, 100231 (2021), https://doi.org/10.1016/j.onehlt.2021.100231

8. P. Purwanto, A.D.P. Citra, Strategies for paint waste minimization in the packaging industry, Waste Technology, 8(1), 18-21 (2020), https://ejournal.undip.ac.id/index.php/wastech/article/view/30464/pdf 
9. P. Purwanto, A.D.P. Citra, H.D. Iswandari, Implementation of occupational health safety in informal industry of paving block and concrete brick, Annals of Tropical Medicine and Public Health, 24 (1), 24-199 (2021), DOI: 10.36295/ASRO.2021.24199

10. Government Regulation No. 74 of 2021 concerning Management of Hazardous and Toxic Materials.

11. Minister of Health of the Republic of Indonesia, Regulation of the minister of health of the Republic of Indonesia no. 75 of 2014 concerning public health centers, (2014)

12. Minister of Health of the Republic of Indonesia, Regulation of minister of health no. 7 of 2019 concerning hospital environmental health, (2019)

13. Government Regulation No. 22 of 2021 concerning the Implementation of Environmental Protection and Management. 